\title{
ACRL at the 1978 Annual Conference
}

Nearly two dozen program sessions were sponsored by ACRL and its various units during the 1978 ALA Annual Conference in Chicago.

President Fldred R. Smith presided over ACRL's principal program, cosponsored by the College and University Libraries Sections. Speakers on the program "The Academic Library within a National Information Policy: Towards the White House Conference and Beyond" were Richard Dougherty, University of California Library, Berkeley; Irma Johnson, Massachusetts Institute of Technology Library; John McGowan, Northwestern University Library; William Moffett, State University of New York Library, Potsdam.

ACRL section programs gave members an oppoftunity to update and share their knowledge of virtually all aspects of academic and research librarianship; these included replevin, library in- struction, preservation of visual resources, automation, and bibliography.

The Agricultural and Biological Sciences Section sponsored the program, "Recombinant DNA - the Right to Know," with a presentation by Jonathan King, director of the Electron Microscope Facility at MIT. The Anthropology Section sponsored a program on the differences between computerized and traditional methods of compiling an anthropological bibliography.

The Asian and African Section addressed the topic of "Bibliographical Control and Library Networks in China, Kuwait and Nigeria." The Bibliographic Instruction Section, offering "The Politics of Libran Instruction," featured a panel of administrators and librarians discussing and exploring their priorities in relation to the problems they have maintaining their priorities.

The Coinmunity and Junior College Libraries
Above, ACRL officers at the 1978 conference (from left to right): Evan i. Farber, Connie R. Dunlap, and Eldred R. Smith. below, ACRL main program speakers (from left to right): Irma Johnson, Richard Dougherty, John McGowan, and William Moffett.
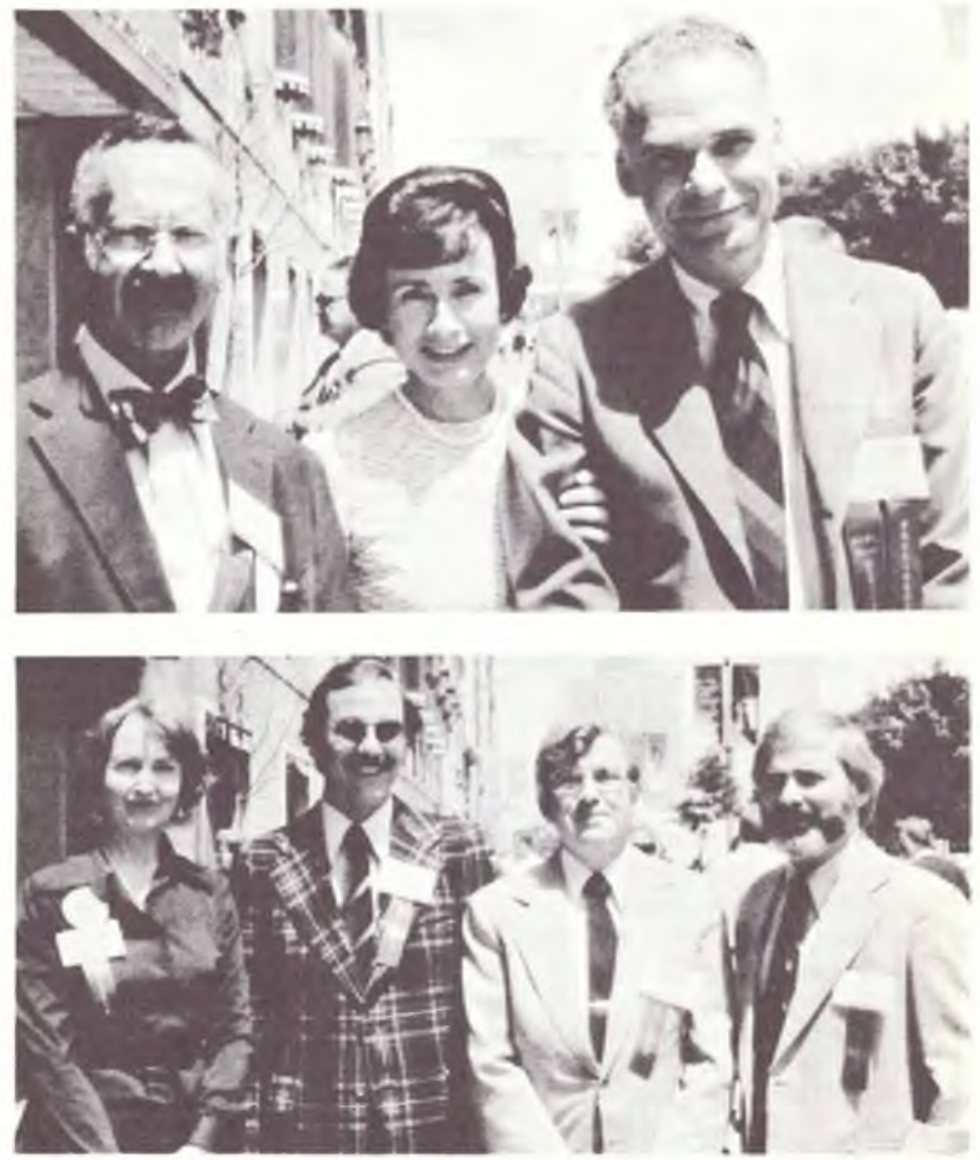
Section, in conjunction with the Public Library Association, offered an all day conferencewithin-a-conference: "Community College and Public Libraries: The Impetus toward Cooperation!" The Rare Books and Manuscripts Section sponsored "Rarities and Ephemera at the Chicago Historical Society Library: an Illustrated Lecture."

The Slavic and East European Section offered a three-part program, which included "Reflec- tions on the History and Prospects of Slavic Bibliography in the United States," "The Automation of Cyrillic Slavic Cataloging," and "Current Developments in Romanization of Cyrillic Scripts."

Trips sponsored by ACRL units included the Law and Political Science Section's tour of Chicago City Hall, the Art Section's boat ride on Lake Michigan, and CJCLS's tour of four libraries of the City Colleges of Chicago.

\section{Association of College and Research Libraries Annual Report of the President 1977-78}

This has been an active and productive year for ACRL. We have addressed or are in the process of addressing several major issues that are of considerable importance to our association and its members.

Plans and arrangements are moving along most efficiently for our first national conference. A major staff appointment was made. Arrangements were worked out for an annual award for achievement by an academic librarian. Other ACRL programs produced results worthy of recognition. In addition, ACRL, during 1977-78, addressed several ALA-wide issues that have significant impact on our association. Finally, we gave attention to concerns that we share with other organizations.

The major critical issues addressed by the association this year included the following. First, we made a beginning evaluation of our association's objectives and the organizational structure needed to carry them out effectively, based upon the report of the special ACRL Ad Hoc Subcommittee on Goals, Priorities, and Structures. Second, we established a mechanism to assist our members in addressing the complex and difficult issues raised by the new copyright legislation. Third, we gave substantive review to the draft university libraries standards prepared by a joint ARL/ACRL committee. Finally, we addressed the particularly complex and critical issues related to ownership of public documents, as raised by the $\mathrm{B}$. C. West case.

The Subcommittee on Goals, Priorities, and Structures was established in the fall of 1973 by ACRL President Norman Tanis with the following charge: (1) to describe the changing environment of research and postsecondary education; (2) to identify the issues and problems relating to information and library service in this environment; (3) to determine the role for an association such as ACRL in responding to these issues and problems; (4) to disregard all financial aspects or the constitutionality of its suggestions.

The committee, chaired by LeMoyne W. Anderson, submitted its recommendations, which included proposals for significant changes in ACRL's activities and structure, in the fall of 1977. The subcommittee's report was referred, by the ACRL board, to our Planning Committee. This committee is reviewing the report and will make recommendations regarding its implementation to the ACRL board.

The Subcommittee on Goals, Priorities, and Structures was discharged with an expression of the board's great appreciation. Certainly, the work of this committee will facilitate ACRL's ability to address the major issues that lie before us. Its recommendations may also contribute to some significant changes in the organization and structure of our association.

Prior to the ALA Midwinter Meeting, ACRL was requested by ALA to assume responsibility for developing guidelines on photocopying of coyrighted materials that could be utilized by academic libraries.

After discussing this issue with William D. North, ALA legal counsel, who met with us at Midwinter, the ACRL board concluded that ACRL should not, at this point, attempt to develop and publicize guidelines in this area. On the other hand, the board recognized the need for identifying, in detail, the problems that academic libraries and librarians are encountering as a result of the new copyright legislation.

Consequently, it was decided that an ad hoc committee on copyright questions should be appointed within ACRL, with the task of identifying questions and issues in this area that are of concern to ACRL members which require legal interpretation or attention. These questions would then be forwarded to North for his review, recommendations, and appropriate legal action on the part of ALA. This committee has been appointed and has set about its task. 